\title{
Developmental Light Environment and Net Gas Exchange of Cocoyam (Xanthosoma sagittifolium)
}

\author{
Hector R. Valenzuela, Stephen K. O'Hair, and Bruce Schaffer \\ Tropical Research and Education Center, IFAS, University of Florida, 18905 S. W. 280 Street, \\ Homestead, FL 33031 \\ Additional index words. aroids, tannia, net carbon dioxide assimilation, photosynthesis, nitrogen, chlorophyll
}

\begin{abstract}
The effects of shade during leaf development on photosynthetic activity of cocoyam [Xanthosoma sagittifolium (L.) Schott] were investigated. Net gas exchange and $\mathbf{N}$ and chlorophyll concentrations were determined for cocoyam leaves growing in $30 \%, 50 \%$, or $100 \%$ sunlight. Net $\mathrm{CO}_{2}$ assimilation (A) and water use efficiency (WUE) were greater for plants grown in $\mathbf{1 0 0 \%}$ sunlight than for plants grown in less sunlight. Substomatal $\mathrm{CO}_{2}$ concentration increased with increased shading. Stomatal conductance $\left(g_{s}\right)$ and transpiration $(E)$ did not vary significantly among treatments. Diurnal paterns for A were positively correlated with $g_{s}$, lamina temperature, relative humidity, and photosynthetic photon flux (PPF). Lamina $\mathbf{N}$ concentrations, determined on lamina dry weight and lamina area bases, increased with increased PPF. Shade plants (30\% and 50\% sunlight) had greater chlorophyll : $N$ ratios (dry-weight basis) and greater lamina area : lamina dry weight ratios than $100 \%$ sunlight-grown plants, which indicates increased photosynthate and $\mathbf{N}$ allocation to leaves of shade plants and maximization of light interception.
\end{abstract}

Cocoyam has been identified as shade tolerant (Caesar, 1980; Schaffer and O'Hair, 1987). Therefore, the potential exists for use of this corm-producing species as an understory crop in polyculture systems. The effect of shading on photosynthetic activity of cocoyam needs to be elucidated to identify optimal photosynthetic photon fluxes (PPF) for maximum yields of this crop. Other aroid species grown in moderate shade have equal (Miura and Osada, 1981), greater (Schaffer and O'Hair, 1987), or lower (Sims and Pearcy, 1989) A rates than sun-grown plants. Schaffer and O'Hair (1987) observed that 60\% sunlight-grown cocoyam had greater A than $100 \%$ sunlight-grown plants. However, their study focused on gas exchange of cocoyam grown at PPFs above the light saturation point for $A\left(>750 \mu \mathrm{mol} \cdot \mathrm{s}^{-1} \cdot \mathrm{m}^{-2}\right)$. Diurnal and seasonal gas exchange data are lacking for cocoyam growing at PPFs below the light saturation point.

Lamina $\mathrm{N}$ and chlorophyll concentrations can affect A (Field, 1983). Chlorophyll is important for light harvesting while $\mathrm{N}$ is an important component of several photosynthetic enzymes (Field, 1983; Evans, 1989). To our knowledge, no information exists that evaluates the role of lamina chlorophyll and $\mathrm{N}$ on shade acclimation of cocoyam.

Previous studies have shown that biomass accumulation and yield of cocoyam are greater for shade-grown than sun-grown plants (unpublished data). The purpose of this study was to determine if the shade-tolerance of cocoyam is related to gas exchange characteristics and to lamina $\mathrm{N}$ and chlorophyll contents of this crop species.

\section{Materials and Methods}

In four separate experiments, 'South Dade White' cocoyam was grown in $100 \%, 50 \%$, or $30 \%$ sunlight [maximum PPF as determined on a cloudless day at $1300 \mathrm{HR}$ with a LI-COR 190SA quantum sensor (LI-COR, Lincoln, Neb.) was 2200, 1100, and $650 \mu \mathrm{mol} \cdot \mathrm{s}^{-1} \cdot \mathrm{m}^{-2}$, respectively]. Mean integrated daily PPFs for the $100 \%$ sunlight treatments were $35.0 \mathrm{~mol} \cdot \mathrm{m}^{-2} \cdot \mathrm{day}^{-1}$ for

\footnotetext{
Received for publication 29 Jan. 1990. Florida Agricultural Experiment Stations Journal Series no. R-00461. We thank R. Fethiere of the Forage Evaluation Support Laboratory, Dept. of Agronomy, Univ. of Florida, for N analysis and F. Martin, Statistics Dept., Univ. of Florida, for statistical analysis advice. The cost of publishing this paper was defrayed in part by the payment of page charges. Under postal regulations, this paper therefore must be hereby marked advertisement solely to indicate this fact.
}

Expts. 1 and 2 , and $37.4 \mathrm{~mol} \cdot \mathrm{m}^{-2} \cdot$ day $^{-1}$ for Expts. 3 and 4 as determined with pyranometer (Model PSP, Eppley Laboratory, Inc., Newport, R.I.). Shade treatments were provided by covering $3 \times 3 \times 1.5-\mathrm{m}$ cages with neutral woven polyethylene fabric of different mesh sizes.

Propagules consisting of the top portion of main corms were potted in 1 peat : 1 sand $(\mathrm{v} / \mathrm{v})$ in 7.5-liter containers. Plants were irrigated daily or every other day, as required, and fertilized twice weekly with 475 ppm N, 104 ppm P, and 192 ppm $\mathrm{K}$, and micronutrients in the irrigation solution. Plants for Expt. 1 were grown in $100 \%$ or $30 \%$ sunlight and plants for Expts. $2-4$ were grown in $100 \%, 50 \%$, or $30 \%$ sunlight. The first two experiments began in June and the last two began in late Dec. 1988.

A, E, $\mathrm{G}_{\mathrm{s}}$, and $\mathrm{Ci}$ were determined in the field by enclosing a portion of the lamina in a Parkinson leaf chamber, connected to a portable $\mathrm{CO}_{2}$ and water vapor exchange analyzer (LCA-2, Analytical Development, Hoddesdon, Herts, U.K.), as described by Schaffer and O'Hair (1987). Outside air containing $340 \pm 10 \mu \mathrm{mol} \mathrm{CO}_{2} / \mathrm{mol}$ and dried to a constant $20 \% \mathrm{RH}$ was pumped into the chamber at a rate of 0.375 liter $\cdot \mathrm{min}^{-1} \mathrm{~A}$ preliminary analysis of light response for $\mathrm{A}$ of mature leaves showed that the saturating PPF for maximum A of cocoyam was $>750$ $\mu \mathrm{mol} \cdot \mathrm{s}^{-1} \cdot \mathrm{m}^{-2}$ (Schaffer and O'Hair, 1987). Therefore, all measurements were made at PPFs $>800 \mu \mathrm{mol} \cdot \mathrm{s}^{-1} \cdot \mathrm{m}^{-2}$ using sunlight as the source. All measurements were made on cloudless days between $0930 \mathrm{HR}$ and $1130 \mathrm{HR}$ to minimize diurnal effects on gas exchange. The experimental design was a randomized complete block with four shade cages (replications) per treatment and four single-plant samples per replication. Gas exchange was determined on the youngest fully expanded leaf of plants in each treatment. Data were analyzed by analysis of variance and by orthogonal contrast analysis. Gas determinations within and between experiments were tested for homogeneity of slopes and intercepts. Gas exchange determinations from all experiments were pooled for statistical analysis when slopes and intercepts were homogeneous.

Diurnal patterns of $\mathrm{A}, \mathrm{g}_{\mathrm{s}}, \mathrm{Ci}, \mathrm{E}, \mathrm{WUE}$, and lamina temperature were determined in the field 95 and 130 days after planting

Abbreviations: A, net $\mathrm{CO}_{2}$ assimilation; $\mathrm{Ci}$, substomatal $\mathrm{CO}_{2}$ concentration; $\mathrm{E}$, transpiration; $\mathrm{g}_{s}$, stomatal conductance; WUE, water use efficiency. 
(DAP) for plants grown in $100 \%$ or $30 \%$ sunlight in Expt. 4. Diurnal gas exchange determination dates were separated by $\approx 1$ month to identify effects of phonological changes (vegetative stage 95 DAP and cormel initiation 130 DAP) on patterns of diurnal gas exchange. Shade-grown plants were removed from the shade and allowed to equilibrate to ambient light for $5 \mathrm{~min}$ before gas exchange determinations. A stepwise regression analysis was performed to evaluate the contribution of diurnal $\mathrm{PPF}$, relative humidity, and lamina temperature to changes in net gas exchange.

Lamina $\mathrm{N}$ and chlorophyll concentrations were determined 140 DAP and again at harvest time in Expt. 3. Samples for $\mathrm{N}$ and chlorophyll determinations consisted of the oldest healthy fully expanded lamina of a plant, one sample per plant. Chlorophyll concentrations were determined as described by Marini and Marini (1983) and Schaffer and Gaye (1989). For N analysis, samples were digested using a modification of the aluminum block procedure of Gallaher et al. (1975). The sample weight was $0.3 \mathrm{~g}$, the catalyst used was $3.2 \mathrm{~g}$ of $9 \mathrm{~K}_{2} \mathrm{SO}_{4}$ : $1 \mathrm{CuSO}_{4}$, and digestion was conducted for $4 \mathrm{hr}$ at $400 \mathrm{C}$ using $10 \mathrm{ml} \mathrm{H}_{2} \mathrm{SO}_{4}$ and $2 \mathrm{ml} \mathrm{H}_{2} \mathrm{O}_{2}$. Ammonia concentration in the digestate was determined by semiautomated calorimetry (Hambleton, 1977) with a Technicon Autoanalyzer-II (Technicon, Tarrytown, N.Y.). Values for $\mathrm{N}$ concentration include organic and inorganic $\mathrm{N}$.

\section{Results}

The effects of shading on net gas exchange of cocoyam were similar in each experiment (slopes of shade vs. gas exchange were homogeneous). Therefore, data from all experiments were pooled to determine effects of shade on net gas exchange. Net $\mathrm{CO}_{2}$ assimilation rates were $8.4,8.8$, and $8.6 \mu \mathrm{mol} \mathrm{CO}_{2} / \mathrm{m}$ per sec for the basal section, midsection, and tip, respectively, of fully expanded laminas. Similarly, laminas of about the same age on the same plant had similar A rates (data not shown). In saturating light, A was greater for $100 \%$ sunlight than for shadegrown $(30 \%$ or $50 \%$ sunlight) cocoyam (Table 1). Transpiration was similar among shade treatments, with mean $\mathrm{E}$ values of 8.1 mmol $\mathrm{H}_{2} \mathrm{O} / \mathrm{m}$ per sec. Net $\mathrm{CO}_{2}$ assimilation increased with increased shade and WUE increased with increased PPF during growth (Table 1).

Ninety-five days after planting, A peaked at $1000 \mathrm{HR}$ and then tended to decrease slightly until 1600 HR (Fig. 1A). Shade plants had lower A than $100 \%$ sunlight-grown plants, but the diurnal pattern was similar for plants grown in both PPF levels (Fig. 1A). Transpiration and WUE showed a similar diurnal pattern as A (Fig. 1D and E). Transpiration was similar during the day for plants exposed to $30 \%$ or $100 \%$ sunlight, while the $100 \%$ sunlight-grown plants had greater WUE values during the early morning hours. Although correlation coefficients were low, A was positively correlated with diurnal PPF $\left[\mathrm{A}=2.83^{-3}\right.$ $(\mathrm{PPF})+1.68 ; r=0.36 ; P<0.01]$ and also with diurnal relative humidity $(r=0.17 ; P<0.01)$. Stomatal conductance decreased throughout the day (Fig. 1C) in relation to decreased relative humidity $\left[\mathrm{g}_{\mathrm{s}}=6.32(\mathrm{RH})-60.03 ; r=0.97 ; \mathrm{P}<\right.$ 0.05], and decreased as vapor pressure deficit (VPD) increased $\left[g_{s}=-71.61(V P D)+456.20 ; r=0.68\right.$ ] (Fig. 1 B and F). Relative humidity and PPF contributed $16 \%$ and $38 \%$, respectively, to the variation in $\mathrm{E}$ throughout the day $\left[\mathrm{E}=1.6^{-3}(\mathrm{PPF})\right.$ $\left.+9.8^{-2}(\mathrm{RH})+1.25 ; P<0.05\right]$.

Nitrogen concentrations on a dry-weight basis increased with increased PPF 140 and 180 DAP (Fig. 2A). Nitrogen contents determined on lamina area (Fig. 2B) and chlorophyll bases increased with increased PPF, 140 DAP. Nitrogen : chlorophyll ratios were 3.7 for $30 \%, 4.2$ for $50 \%$, and 4.6 for $100 \%$ sunlight-grown plants. No significant differences were found in lamina chlorophyll contents between shade treatments 140 or 180 DAP; chlorophyll $(\mathrm{a}+\mathrm{b})$ contents ranged from 0.39 to $0.42 \mathrm{mg} \cdot \mathrm{cm}^{-2}$. No differences in chla : chlb ratios were observed between treatments with ratios ranging from 1.4 to 1.8 when determined on both dry-weight and lamina-area bases. There was a positive relationship between $\mathrm{N}$ concentration (dryweight basis) and chlorophyll concentration (chlorophylls a and b, fresh-weight basis) 180 DAP $[\mathrm{N}=7.73(\mathrm{CHL})+258.56$; $r=0.49 ; P<0.05]$. Specific leaf density was greater for $100 \%$ than for $30 \%$ sunlight-grown plants 140 and 180 DAP (Fig. 3).

\section{Discussion}

Although cocoyam has been reported to be shade-tolerant (Ceasar, 1980; Schaffer and O'Hair, 1987), it responded to increased PPF during plant development with increased A. Despite lower A, shade-grown plants had greater foliage and storage organ biomass (unpublished data) than full sun-grown plants. The increased leaf area in the shade resulted in increased photosynthate production and likely more partitioning to underground storage organs.

Shaded cocoyam yielded more than cocoyam grown in full sun (unpublished data). In the present experiment, plants grown in full sun had both greater lamina $\mathrm{N}$ contents (on an area and a chlorophyll basis) and $\mathrm{A}$. Therefore, lamina $\mathrm{N}$ content may play a role in the adaptation of cocoyam to varying developmental PPF as shown for several plant species (Sims and Pearcy, 1989; Syvertsen and Smith, 1984; Thompson et al., 1988).

Table 1. Effect of developmental light environment on $\mathrm{A}, \mathrm{g}_{\mathrm{s}}, \mathrm{Ci}$, and WUE of cocoyam determined under saturating PPF $\left(800 \mu \mathrm{mol} \cdot \mathrm{s}^{-1} \cdot \mathrm{m}^{-2}\right) .^{2}$

\begin{tabular}{lcccc}
\hline \hline Sunlight $(\%)$ & $\begin{array}{c}\mathrm{A} \\
(\mu \mathrm{mol} \mathrm{CO} / \\
\mathrm{m} \mathrm{per} \mathrm{sec})\end{array}$ & $\begin{array}{c}\mathrm{g}_{\mathrm{s}} \\
(\mathrm{mmol} \mathrm{CO} / \\
\mathrm{m} \mathrm{per} \mathrm{sec})\end{array}$ & $\begin{array}{c}\mathrm{Ci} \\
\left(\mu \mathrm{mol} \mathrm{CO}_{2} /\right. \\
\mathrm{mol})\end{array}$ & $\begin{array}{c}\text { WUE } \\
\left(\mathrm{mmol} \mathrm{CO}_{2} /\right. \\
\left.\mathrm{mol} \mathrm{H}_{2} \mathrm{O}\right)\end{array}$ \\
\hline 100 & 8.8 & 237 & 263 & 1.2 \\
50 & 8.1 & 231 & 269 & 1.1 \\
30 & 6.7 & 210 & 273 & 0.9 \\
Orthogonal contrasts & $*$ & & $*$ & $*$ \\
Shade linear & $\mathrm{NS}$ & $\mathrm{NS}$ & $*$ & $\mathrm{NS}$ \\
Shade quadratic & & $\mathrm{NS}$ & $*$
\end{tabular}

${ }^{z}$ Determinations for all experiments were pooled because slopes and intercepts were homogeneous.

NS, * Nonsignificant and significant at $P<0.05$, respectively. 


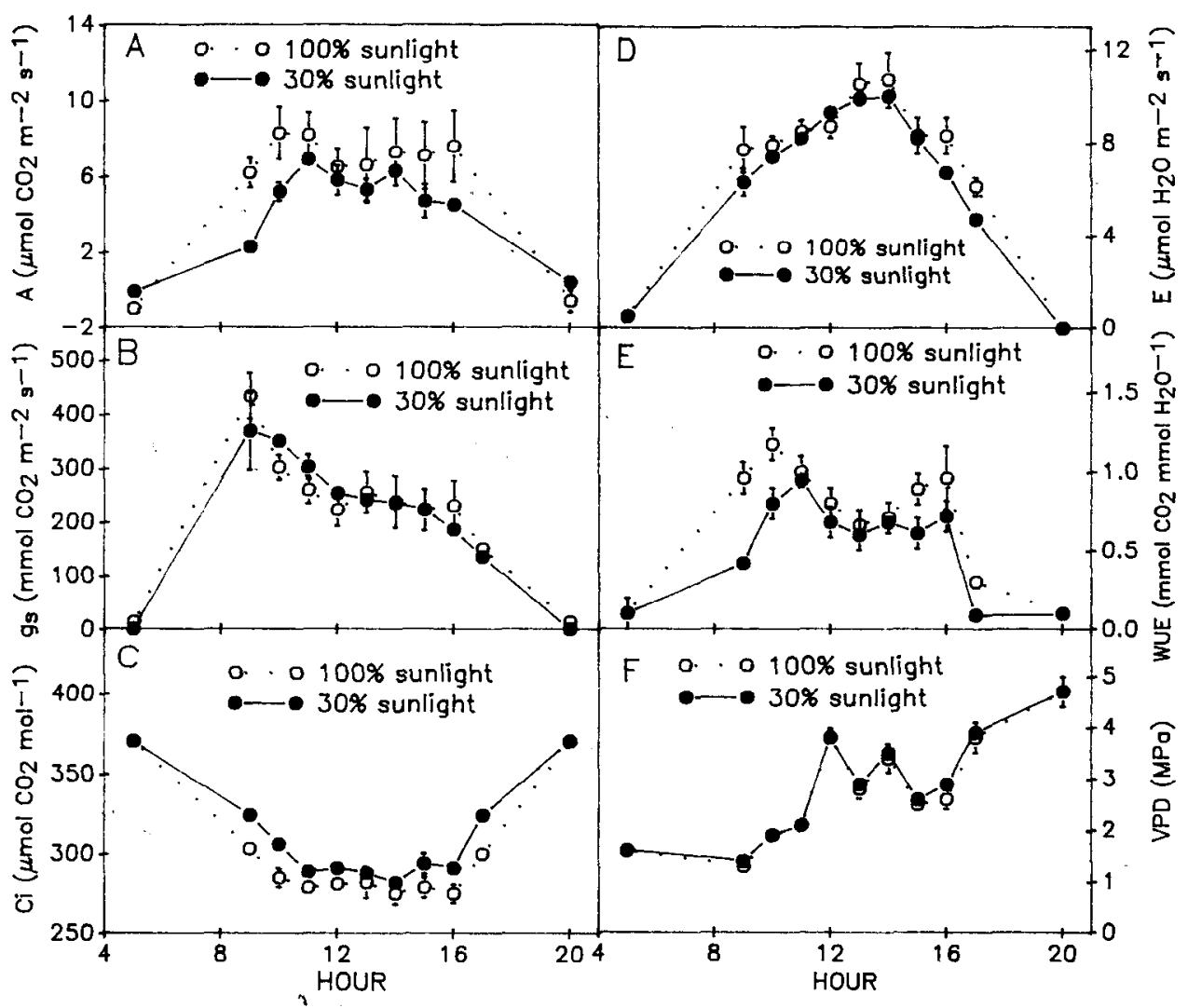

Fig: 1. Diurnal patterns of net $\mathrm{CO}_{2}$ assimilation (A), stomatal conductance for $\mathrm{CO}_{2}(\mathbf{B})$, substomatal $\mathrm{CO}_{2}$ concentration $(\mathbf{C})$, transpiration $(\mathbf{D})$, water use efficiency $(\mathbf{E})$, and vapor pressure deficit (F) of cocoyam grown in $100 \%$ or $30 \%$ sunlight. Each point represents the mean of four replications $\pm S E$ determined on 5 Apr. 1989 (95 days after planting). In some cases SE bars were smaller than the symbols.

Increased A with increasing developmental PPF has been reported for other plant species (Evans, 1989), including related aroids (Sims and Pearcy, 1989). Lower respiration rates for several shade-grown plants than for plants grown in direct sunlight (Bjorkman, 1981; Givnish, 1988; Miura and Osada, 1981; Sims and Pearcy, 1989) may be a compensation for decreased $\mathrm{A}$ in the shade, resulting in an overall increased net biomass accumulation for shade-adapted plants grown in low PPFs (Bjorkman, 1981). In the present experiment, the lower tissue biomass on a lamina area basis for plants in $30 \%$ sunlight than for plants in $100 \%$ sunlight (Fig. 3) indicated that shade plants had lower maintenance costs than plants grown in $100 \%$ sunlight (Bjorkman, 1981; Givnish, 1988).

The PPF at which A reached its maximum value was similar to that reported for Colocasia (Schaffer and O'Hair, 1987; Sims and Pearcy, 1989) but greater than that observed for Alocasia, another aroid (Sims and Pearcy, 1989). Aocasia is adapted to growing in deep-shaded forest understories, while both cocoyam and Colocasia, are often grown in monoculture that allow for greater light absorption by individual plants (Schaffer and O'Hair, 1987). The high $\mathrm{g}_{\mathrm{s}}(>200 \mathrm{mmol} \mathrm{CO} / \mathrm{m}$ per see) in the present study indicates that $\mathrm{g}_{\mathrm{s}}$ was not limiting photosynthetic activity (Kirschbaum and Pearcy, 1988). The greater WUE obtained for $100 \%$ than for $30 \%$ sunlight-grown plants indicates that the former were better adapted to absorb and use the high PPFs (> $800 \mu \mathrm{mol} \cdot \mathrm{s}^{-1} \cdot \mathrm{m}^{-2}$ ) at which the gas exchange measurements were taken.

The trend toward a diurnal decline in A observed at midday may be attributable to stomatal closure due to water and/or heat stress, or to inherent diurnal behavior (Kirschbaum et al., 1988). However, the diurnal decline in A coincided with an increase of $\mathrm{CO}_{2}$ in the substomatal cavity. Although recent studies indicated that $\mathrm{Ci}$ may be overestimated from gas exchange calculations (Downton et al., 1988), increased Ci with decreasing A generally indicates a nonstomatal limitation to gas exchange (Farquhar and Sharkey, 1982). Therefore, during prolonged periods of high PPF, sun- and shade-grown cocoyam leaves may be photoinhibited. Photoinhibition due to prolonged exposure to high PPF has also been observed for Vitis vinifera L. leaves (Correia et al., 1990). The depletion of $\mathrm{CO}_{2}$ in substomatal cavities was greater for plants grown in full sun (Table 1, Fig. 1C) due to their greater photosynthetic activity compared to shade-grown plants. The declining trend in A from midday corresponded with decreased $g_{s}$, E, WUE, and relative humidity and increased vapor pressure deficit. Stomatal conductance for $\mathrm{CO}_{2}$ decreased throughout the day, possibly due to stomatal closure in response to increased vapor pressure deficit (Henson et al., 1989; Kuppers and Schulze, 1985; Nowak et al., 1988; San Jose, 1983).

The data obtained in this study indicate that gas exhange and $\mathrm{N}$ content of cocoyam are affected by incident PPF during plant growth. The greater A (on a leaf-area basis) for $100 \%$ sunlightgrown cocoyam may partially compensate for the lower leaf area for the $100 \%$ sunlight-grown plants compared to shadegrown plants (unpublished data). This compensation may explain cocoyam's ability to grow and produce marketable yields in a wide range of light environments. 


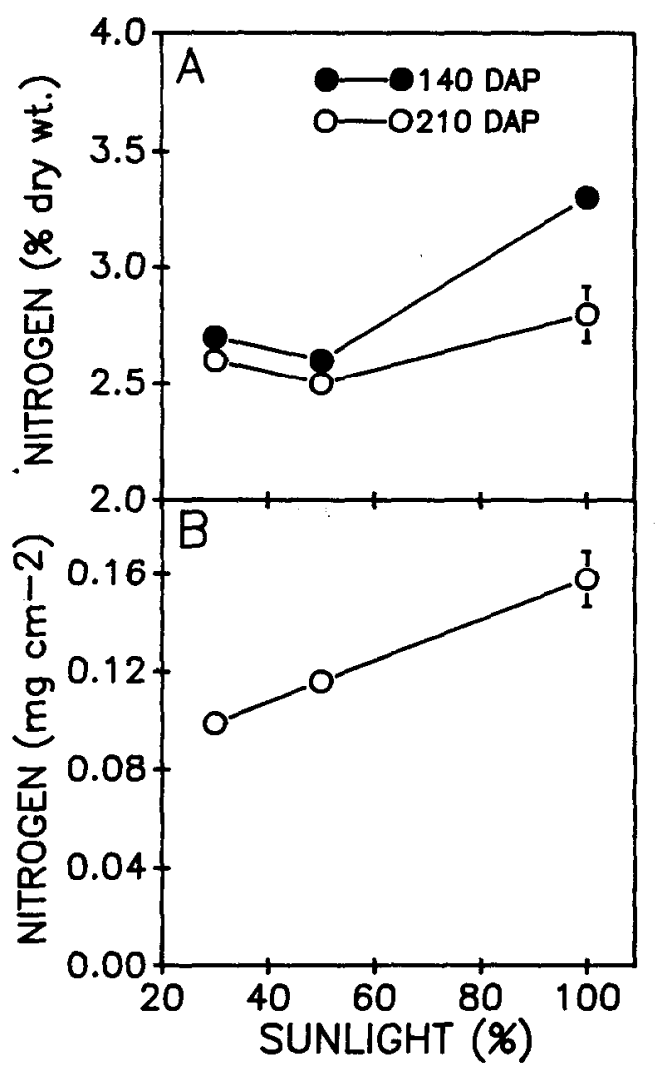

Fig. 2. Effect of sunlight on lamina $\mathrm{N}$ concentration on a lamina dry weight (A), and area basis (140 days after planting) (B) of cocoyam in Expt. 3. Each point represents the mean of 10 replications \pm SE 140 davs after planting, and of six replications \pm SE 210 days after planting. In most cases SE bars were smaller than the symbols.

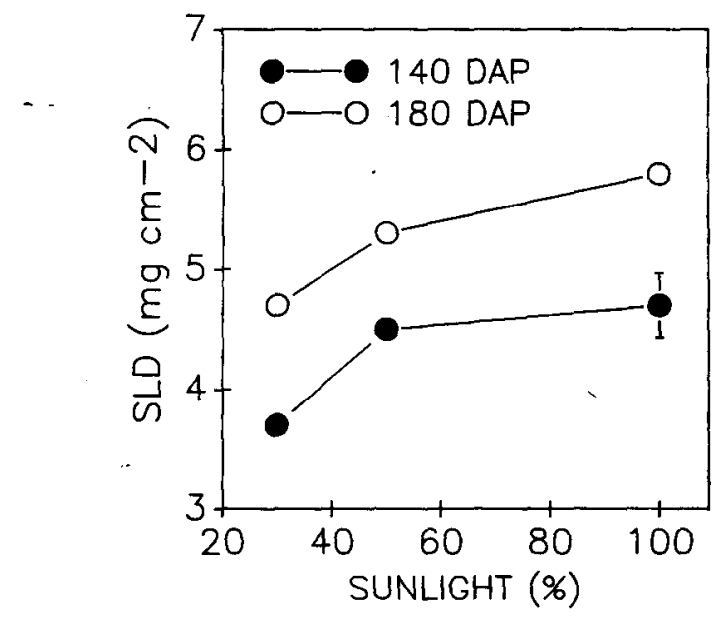

Fig. 3. Effect of sunlight on specific leaf density (SLD) of cocoyam in Expt. 3. Each point represents the mean of 10 replications $\pm S E$. In most cases SE bars were smaller than the symbols.

\section{Literature Cited}

Bjorkman, O. 1981. Responses to different quantum flux densities, p. 57-107. In: O.L. Lange, P.S. Nobel, C.B. Osmond, and H. Ziegler (eds.). Physiological plant ecology I. Encyclopedia of plant physiology. vol. 12A, Springer-Verlag, Berlin.

Caesar, K. 1980. Growth and development of Xanthosoma and Col- ocasia under different light and water supply conditions. Field Crops Res. 3:235-244.

Correia, M.J., M.M.C. Chaves, and J.S. Pereira. 1990. Afternoon depression in photosynthesis in grapevine leaves-evidence for a high light stress effect. J. Expt. Bot. 41:417-426.

Downton, W.J.S., B.R. Loveys, and W.J.R. Grant. 1988. Stomatal closure fully accounts for the inhibition of photosynthesis by abscisic acid. New Phytologist 108:263-266.

Evans, J.R. 1989. Photosynthesis and nitrogen relationships in leaves of $C_{3}$ plants, Oecologia 78:9-19.

Farquhar, G.D. and T.D. Sharkey. 1982. Stomatal conductance and photosynthesis. Annu. Rev. Plant Physiol. 33:317-345.

Field, C. 1983. Allocating leaf nitrogen for the maximization of carbon gain: leaf age as a control on the allocation program. Oecologia 56:341-347.

Gallaher, R.N., C.O. Weldon, and J.G. Futral. 1975. An aluminium block digester for plant and soil analysis. Soil Sci. Soc. Amer. Proc. 39:803-806.

Givnish, T.J. 1988. Adaptation to sun and shade; a whole-plant perspective. Austral. J. Plant Physiol. 15:63-92.

Hambleton, L.G. 1977. Semiautomated method for simultaneous determinations of phosphorus, calcium and crude protein in animal feeds. J. Assn. Offic. Anal. Chem. 60:845-852.

Henson, I.E., C.R. Jensen, and N.C. Turner. 1989. Leaf gas exchange and water relations of lupins and wheat. I. Shoot responses to soil water deficits. Austral. J. Plant Physiol. 16:401-413.

Kirschbaum, M.U.F. and R.W. Pearcy. 1988. Gas exchange analysis of the relative importance of stomatal and biochemical factors in photosynthetic induction in Alocasia macrorrhiza. Plant Physiol. 86:782-785.

Kirschbaum, M.U.F., J.F. Gross, and R.W. Pearcy. 1988. Observed and modelled stomatal responses to dynamic light environments in the shade plant Alocasia macrorrhiza. Plant Cell \& Env. 11:111121.

Kuppers, M. and E.D. Schulze. 1985. An empirical model of net photosynthesis and leaf conductance for the simulation of diurnal courses of $\mathrm{CO}_{2}$ and $\mathrm{H}_{2} \mathrm{O}$ exchange. Austral. J. Plant Physiol. 12:513526.

Marini, R.P. and M.C. Marini. 1983. Seasonal changes in specific leaf weight, net photosynthesis, and chlorophyll content of peach leaves as affected by light penetration and canopy position. J. Amer. Soc. Hort. Sci. 108:600-605.

Miura, K. and A. Osada. 1981. Effect of shading on photosynthesis, respiration, leaf area and corm weight in konjak plants (Amorphophallus konjak K. Koch). Jpn. J. Crop Sci. 50:553-559.

Nowak, R.S., J.E. Anderson, and N.L. Toft. 1988. Gas exchange of Agropyron desertorum: diurnal patterns and responses to water vapor gradient and temperature. Oecologia 77:289-295.

San Jose, J.J. 1983. Diurnal course of $\mathrm{CO}_{2}$ and water vapour exchange in Manihot esculenta Crantz var. cubana. Photosynthetic 17:1219.

Schaffer, B. and S.K. O'Hair. 1987. Net $\mathrm{CO}_{2}$ assimilation of taro and cocoyam as affected by shading and leaf age. Photosynthesis Res. 11:245-251.

Schaffer, B. and G.O. Gaye. 1989. Gas exchange, chlorophyll and nitrogen content of mango leaves as influenced by light environment. HortScience 24:507-509.

Sims, D.A. and R.W. Pearcy. 1989. Photosynthetic characteristics of a tropical forest understory herb, Alocasia macrorrhiza, and a related crop species, Colocasia esculenta grown in contrasting light environments. Oecologia 79:53-59.

Syvertsen, J.P. and M.L. Smith Jr. 1984. Light acclimation in citrus leaves. I. Changes in physical characteristics, chlorophyll, and nitrogen content. J. Amer. Soc. Hort. Sci. 109:807-812.

Thompson, W.A., G.C. Stocker, and P.E. Kridemann. 1988. Growth and photosynthetic response to light and nutrients of Flindersia brayleyana F. Muell., a rainforest tree with broad tolerance to sun and shade. Austral. J. Plant Physiol. 15:299-316. 